\section{Physical weathering by glaciers enhances silicon mobilisation and isotopic fractionation}

\author{
J.E. Hatton ${ }^{1,2 *}$, K.R. Hendry ${ }^{2}$, J.R. Hawkings ${ }^{3,4}$, J.L. Wadham ${ }^{5,6}$, L.G. Benning ${ }^{4,7}$, \\ R. Blukis ${ }^{4}$, V. Roddatis', H.C. Ng${ }^{2}$, T. Wang ${ }^{2}$
}

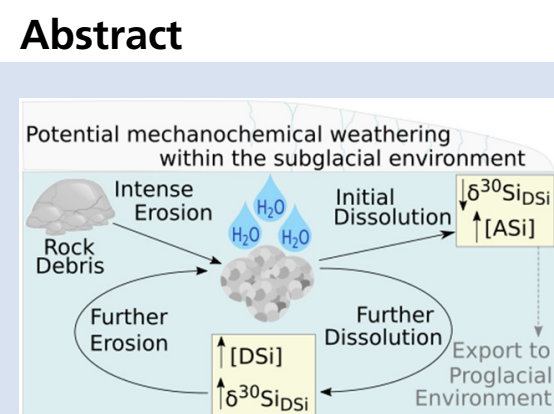

Glacial meltwaters export substantial quantities of dissolved and dissolvable amorphous silicon (DSi and ASi), providing an essential nutrient for downstream diatoms. Evidence suggests that glacially exported DSi is isotopically light compared to DSi in non-glaciated rivers. However, the isotopic fractionation mechanisms are not well constrained, indicating an important gap in our understanding of processes in the global Si cycle. We use rock crushing experiments to mimic subglacial physical erosion, to provide insight into subglacial isotope fractionation. Isotopically light DSi $\left(\delta^{30} \mathrm{Si}_{\mathrm{DS}}\right)$ released following initial dissolution of freshly ground mineral surfaces (down to $-2.12 \pm 0.02 \%$ ) suggests mechanochemical reactions induce isotopic fractionation, explaining the low $\delta^{30} \mathrm{Si}_{\mathrm{DS}}$ composition of subglacial runoff. ASi with a consistent isotopic composition is present in all mechanically weathered samples, but concentrations are elevated in samples that have undergone more intense physical grinding. These experiments illustrate the critical role of physical processes in driving isotopic fractionation and biogeochemical weathering in subglacial environments. Understanding perturbations in high latitude Si cycling under climatic change will likely depend on the response of mechanochemical weathering to increased glacial melt.

Received 26 August 2020 | Accepted 17 August 2021 | Published 6 October 2021

\section{Introduction}

Glaciers and ice sheets are dynamic sources of nutrients and reactive particulate material to downstream ecosystems (e.g., Wadham et al., 2010; Hawkings et al., 2015; Sharp and Tranter, 2017). There is evidence that silicate mineral weathering is enhanced beneath large ice sheets (Wadham et al., 2010; Michaud et al., 2016), which may contribute significant fluxes of dissolved silicon and dissolvable amorphous silica (DSi and ASi respectively) downstream, stimulating productivity of siliceous organisms (Hendry et al., 2019).

The stable silicon isotopic composition (denoted by $\delta^{30} \mathrm{Si}$ ) of glacial meltwaters can aid mechanistic understanding of subglacial weathering processes (Opfergelt et al., 2013; Hawkings et al., 2018; Hatton et al., 2019a). Previous work has hypothesised that physical weathering in the subglacial environment results in isotopically light DSi in glacial meltwaters when compared to non-glacial riverine waters (Hatton et al., 2019b). This is likely due to the creation of highly reactive mineral surfaces combined with chemical precipitation-dissolution reactions, which result in the formation and preferential dissolution of isotopically depleted amorphous weathering crusts (Opfergelt et al., 2013;
Hatton et al., 2019b). The high levels of physical erosion and sediment comminution in subglacial environments, combined with chemical weathering act to enhance the export of DSi from subglacial environments. However, a better understanding of subglacial silicate dissolution and associated $\mathrm{Si}$ isotopic fractionation is required to constrain the impacts of changing glacial environments on wider associated elemental cycles (e.g., nutrient liberation from silicate minerals and long term carbon drawdown from silicate weathering) and enable the inclusion of glacially exported Si in global biogeochemical models.

A large proportion of the glacial Si flux is likely exported as ASi. Field observations from Leverett Glacier, Greenland reveal up to $95 \%$ of $\mathrm{Si}$ exported is $\mathrm{ASi}$, which is soluble in downstream marine environments (Hawkings et al., 2017). The potential ASi formation mechanisms to explain elevated glacial ASi concentrations include dissolution-reprecipitation weathering where ASi forms via supersaturation at the grain boundary (Hellmann et al., 2012), and chemically leached particle surface layers resulting in an amorphous crust of less soluble ions such as Si (Casey et al., 1993). Additionally, silicate dissolution and ASi formation have been linked to physical processes, with ASi hypothesised to form as a disturbed surface layer (Blackburn et al., 2019; Hatton et al.,

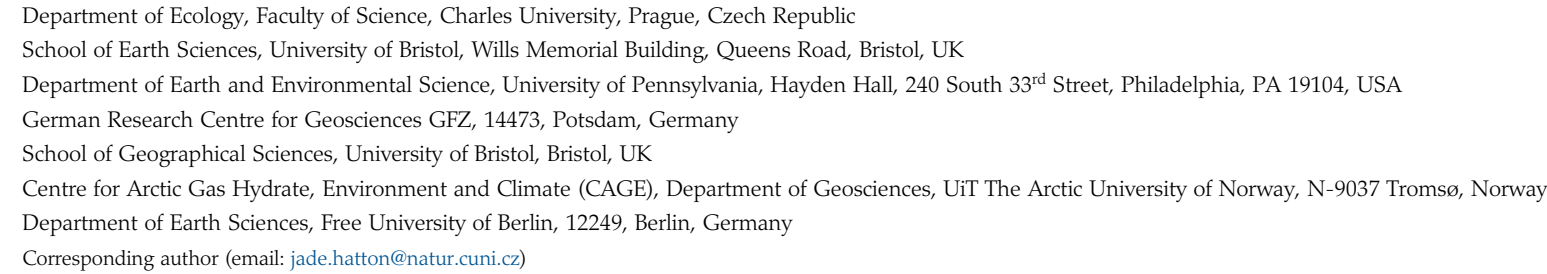


2019b). This combination of physical erosion and chemical weathering (i.e. mechanochemical) could be key to understanding subglacial processes, considering high erosion rates and large surface areas of sediments in subglacial environments.

We tested the hypotheses that high physical erosion rates in subglacial environments result in (i) isotopically light DSi via the production of highly reactive fine grained glacial flour (Opfergelt et al., 2013; Hatton et al., 2019b), and (ii) the formation of ASi. Dissolution experiments (Fig. 1) mimicked mechanochemical processes in the subglacial system to ascertain the role of physical weathering on $\mathrm{Si}$ concentrations and $\delta^{30} \mathrm{Si}$ composition (see Supplementary Information for full methodology). Pre-weathered unsorted glacial till (dominantly plagioclase and quartz; Fig. S-1) from Leverett Glacier proglacial plain (LG; Fig. S-2) was mechanically milled for either 2 (T2) or 30 (T30) minutes in an agate mill (note that ASi concentrations produced when milling in agate or steel mills were within analytical error, showing no significant contamination source from the agate mill, see Supplementary Information) and reacted for up to 720 hours with ultra-pure water $(18.2 \mathrm{M} \Omega \mathrm{cm}$, Millipore $囚)$. The milled and reacted powders were then re-dried, re-crushed and reacted again to mimic ongoing physical erosion within a subglacial

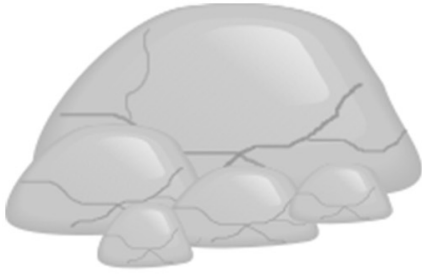

Bulk Proglacial Debris, Leverett Glacier
Hammer and Plate

$$
<2 \mathrm{~mm}
$$

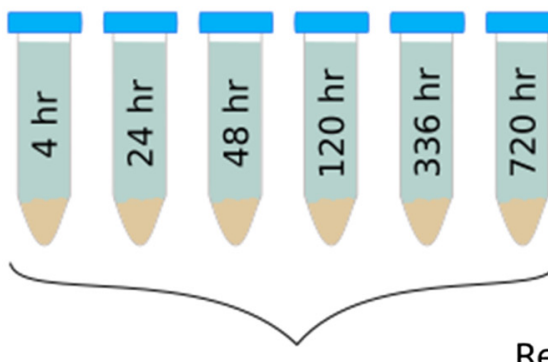

Replicates $\times 3$

$2 \mathrm{~g}$ crushed rock $+40 \mathrm{~mL}$ Milli Q Water

Shaker @ 100 r.p.m., 4

\section{Ball Mill 2 minutes}

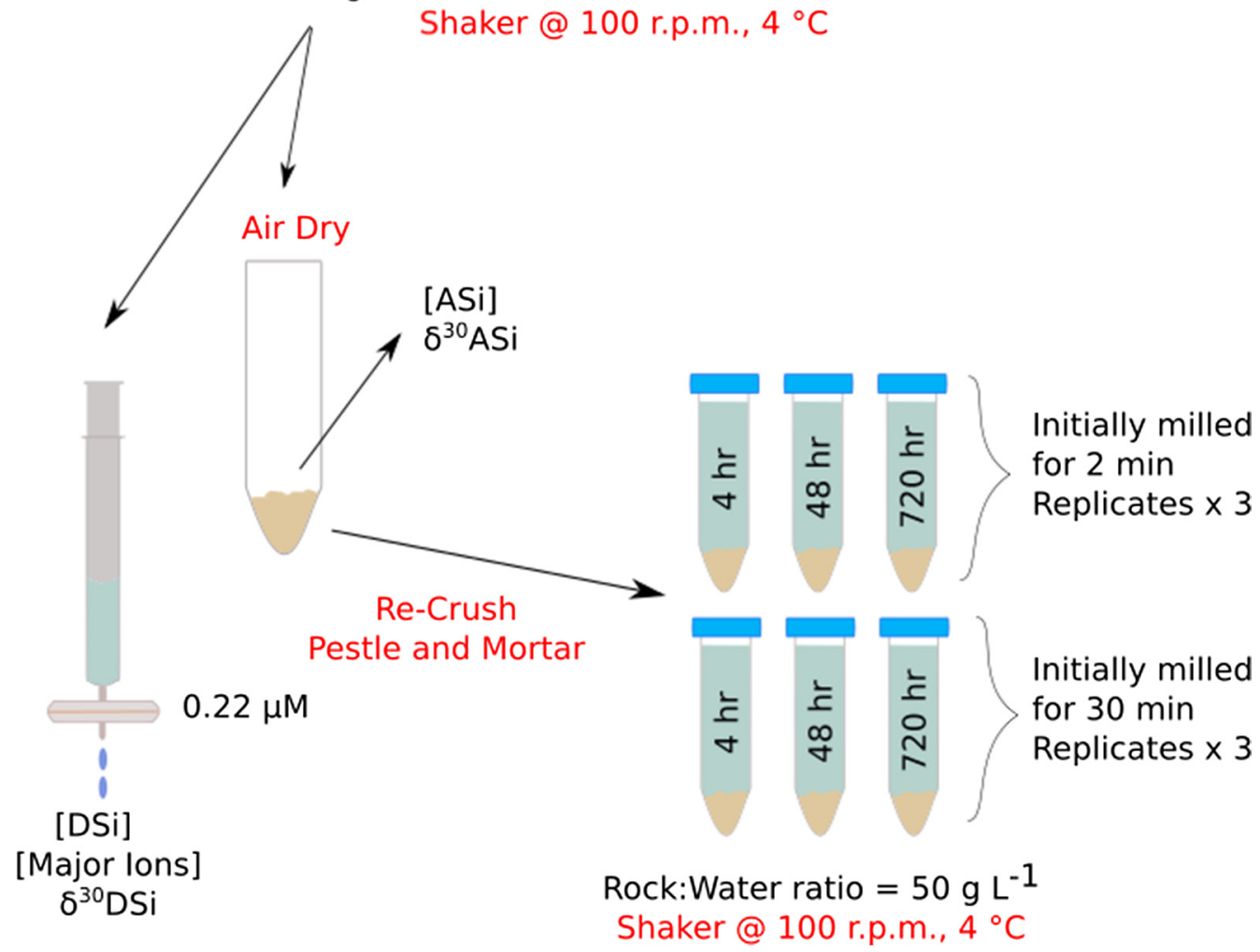

Figure 1 Illustration of the experimental set up. 
environment (Fig. 1). We chose to use field collected samples for these experiments to better mimic real world conditions and compare to existing field data.

\section{Results and Discussion}

Dissolution of freshly exposed mineral surfaces drives isotopically light DSi. Our experiments highlight the likely importance of physical erosion processes in subglacial environments. Rapid dissolution of $\mathrm{Si}$ after initial milling and after re-crushing led to $\delta^{30} \mathrm{Si}_{\mathrm{DSi}}$ values (down to $-2.12 \%$ ) more depleted than values recorded in subglacial meltwater sourced DSi $(+1.01$ to $-0.58 \%$; Hatton et al., 2019b). The lowest $\delta^{30} \mathrm{Si}_{\mathrm{DSi}}$ composition for T2 and T30 was measured after 4 hours, with $\delta^{30} \mathrm{Si}_{\mathrm{DSi}}$ increasing over time (Fig. 2, Table S-1). The preferential release of lighter Si isotopes during dissolution relates to the distribution of ${ }^{28} \mathrm{Si}$ and ${ }^{29} \mathrm{Si}$ on surface layers. Our experiments agree with previous experiments that show physical grinding leads to the preferential release of ${ }^{28} \mathrm{Si}$ during initial dissolution of fresh surface layers, which suggests a higher abundance of ${ }^{28} \mathrm{Si}$ on the surface of freshly ground minerals in the destabilised outer layers of the crystal structure (Ziegler et al., 2005). It's likely that the high surface areas created by physical grinding led to rapid initial dissolution of $\mathrm{Si}$, with the largest isotopic fractionation. As the experiment progressed, the $\delta^{30} \mathrm{Si}_{\mathrm{DSi}}$ composition increased

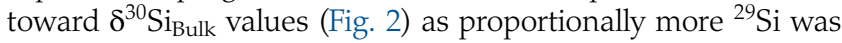
liberated from internal crystalline structures.

After the reacted material was re-crushed, the $\delta^{30} \mathrm{Si}_{\mathrm{DSi}} \mathrm{com}-$ position decreased again (down to $-1.29 \%$; Fig. 2, Table S-2). The decrease in $\delta^{30} \mathrm{Si}_{\mathrm{DSi}}$ composition after re-crushing, suggests that the regeneration of reactive mineral surface layers by physical action promotes further dissolution of isotopically light $\mathrm{Si}$. This process presents a viable mechanism to explain isotopically light DSi in glacial meltwaters, due to the continuous comminution of bedrock in the subglacial system.

Our findings of initial dissolution resulting in low $\delta^{30} \mathrm{Si}_{\mathrm{DSi}}$ composition are consistent with results of leaching experiments on basaltic lavas (Ziegler et al., 2005) and diatom opal (Demarest et al., 2009), suggesting this process is independent of sediment lithology. While our experiments do not isolate the exact mechanism driving the apparent fractionation during initial dissolution, they do suggest that continuous comminution of subglacial sediments results in exposure of fresh, large surface areas. This reactive surface layer promotes the dissolution of Si and
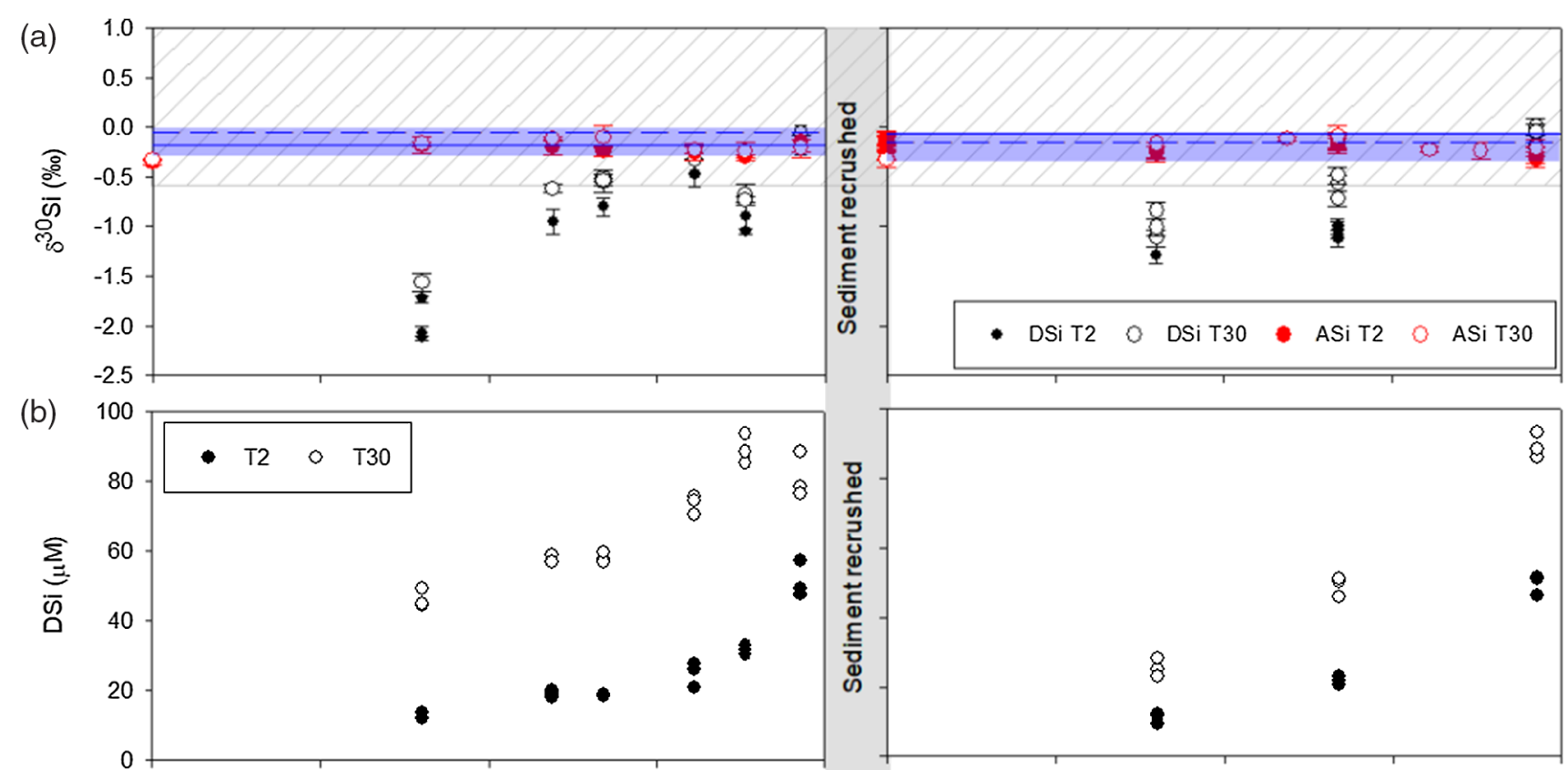

(c)
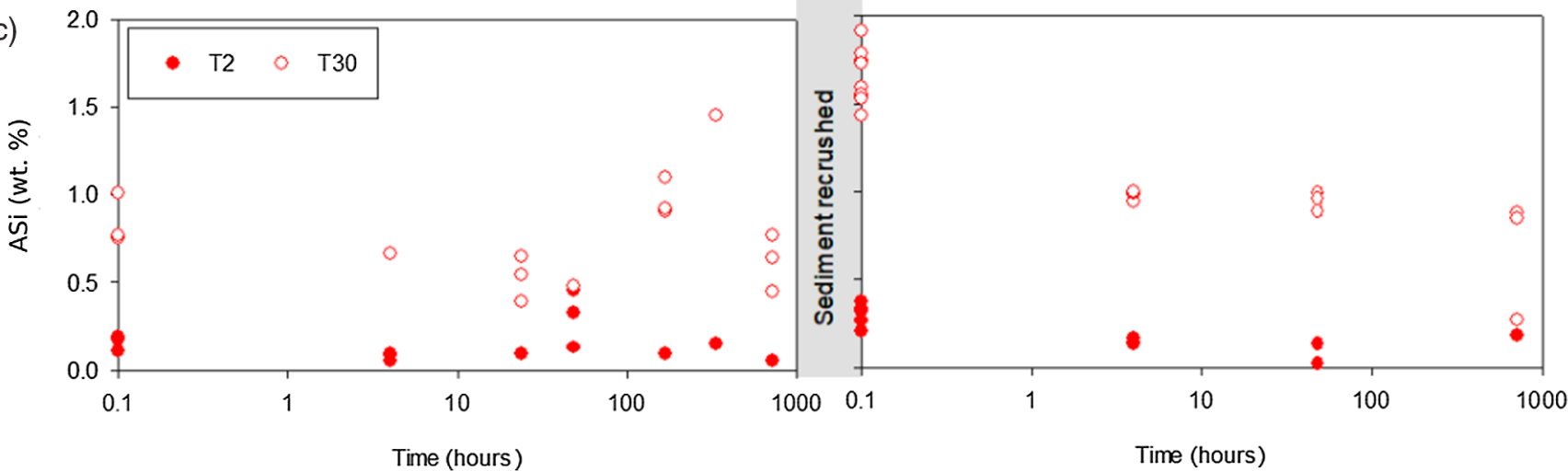

Figure 2 Geochemical results of primary and crushing experiments over time. $\mathrm{DSi}=$ black, $\mathrm{ASi}=$ red, closed $=\mathrm{T} 2$, open $=\mathrm{T} 30$. (a) $\delta^{30} \mathrm{Si}_{\mathrm{DSi}}$ and $\delta^{30} \mathrm{Si}_{\mathrm{ASi}}$ composition, error bars represent average external error $\left(0.08 \%\right.$, 2 s.d.). Blue horizontal lines mark $\delta^{30} \mathrm{Si}$ composition of bulk rock (T2 = solid, T30 = dashed), with 2 s.d. external error shaded blue. (b) DSi concentrations. (c) ASi concentrations. Initial and secondary milled data separated by vertical grey area. Glacial river $\delta^{30} \mathrm{Si}_{\mathrm{DSi}}$ range from -0.58 to $+1.01 \%$ (grey hashed region) and glacial $\delta^{30} \mathrm{Si}_{\mathrm{ASi}}$ ranges from -0.86 to $-0.05 \%$ (Hatton et al., 2019b). 
drives the light $\delta^{30} \mathrm{Si}_{\mathrm{DSi}}$ composition in glacial meltwaters (Opfergelt et al., 2013; Hatton et al., 2019b).

The degree of isotopic fractionation does not appear to scale with DSi concentration and the available surface area. T2 experiments had lighter $\delta^{30} \mathrm{Si}_{\mathrm{DSi}}$ composition than T30 for all timepoints (Fig. 2), despite lower DSi concentrations (Fig. 2) and lower specific surface area deduced from mean grain size of material (Fig. S-3; Telling et al., 2015). There are potential explanations for this, considering i) isotopic heterogeneity within the starting material, ii) natural pre-weathering of rock material, and/or iii) ASi formation and dissolution. The rocks used in this experiment from the proglacial plain, are naturally heterogeneous, and were pre-weathered within the sub- and proglacial environment. We see evidence of amorphous $\mathrm{SiO}_{2}$ nanoparticles in all samples via HR-TEM imaging (see Fig. 4), highlighting a degree of environmental pre-weathering prior to sample collection. This pre-weathering of material could have resulted in surface layers with a lower $\delta^{30} \mathrm{Si}$ composition compared to the bulk rock material due to the fractionation induced by weathering processes (Frings et al., 2016). When the rocks were milled for a short time (T2), the fresh mineral surfaces were comparatively enriched with Si from these pre-weathered surfaces (e.g., isotopically light amorphous nanoparticles). Whereas, longer milling in T30 exposed more of the non-weathered crystalline structure from where proportionally more DSi was derived. This could explain why T30 DSi was marginally closer to the bulk rock value $(-0.13 \pm 0.16 \%$ o). Alternatively, the higher ASi concentrations in T30 experiments may have impacted the overall $\delta^{30} \mathrm{Si}_{\mathrm{DS}}$ composition. Previous experiments have shown large isotopic fractionations (up to $-7.5 \%$ ) associated with quartz cement dissolution and precipitation (Basile-Doelsch et al., 2005). If there was proportionally greater ASi dissolution in T30 experiments, when compared to T2 experiments, then this could have resulted in a smaller overall fractionation in T30 and a less depleted $\delta^{30} \mathrm{Si}_{\mathrm{DSi}}$ composition.

Our experiments do not allow for a detailed analysis of the difference in $\delta^{30} \mathrm{Si}_{\mathrm{DSi}}$ composition between $\mathrm{T} 2$ and $\mathrm{T} 30$ resulting from dissolution, particularly with the potential impacts of the environmental pre-weathering. However, the overall differences are small compared to the large fractionation observed after initial dissolution. Therefore, we hypothesise that continuous subglacial physical erosion of bedrock could lead to isotopically low $\delta^{30} \mathrm{Si}_{\mathrm{DSi}}$ after wetting sediments with dilute waters. This process would likely explain the observed low meltwater $\delta^{30} \mathrm{Si}_{\mathrm{DSi}}$ composition (Hatton et al., 2019b).

Mechanochemical reactions may promote ASi formation in subglacial systems. A more robust understanding of the formation process of subglacial ASi is important considering the large flux term of glacial ASi to downstream environments (Hawkings et al., 2017). We use these experiments to deduce the potential role of physical erosion in ASi formation. ASi concentrations were consistently higher in T30 compared to T2 (Fig. 3, Tables S-1, S-2) after both the initial milling (T30 0.8 \% d.w., T2 $0.2 \%$ d.w.) and then re-crushing (T30 $1.2 \%$ d.w., T2 $0.3 \%$ d.w.), indicating that more intense physical erosion and generation of larger particle surface areas resulted in higher observed ASi concentrations. The increase in ASi from the end of the initial dissolution to when the material was re-crushed also indicates that the secondary crushing regenerates fresh amorphous mineral surfaces. It is likely that the milling process results in greater ASi formation, which is more soluble as a result of a greater surface area from longer milling times. Elevated ASi concentrations from crushing are consistent with field observations of ASi-rich precipitates produced by subglacial physical and chemical weathering processes during the last glaciation (Blackburn et al., 2019), and ASi formation by

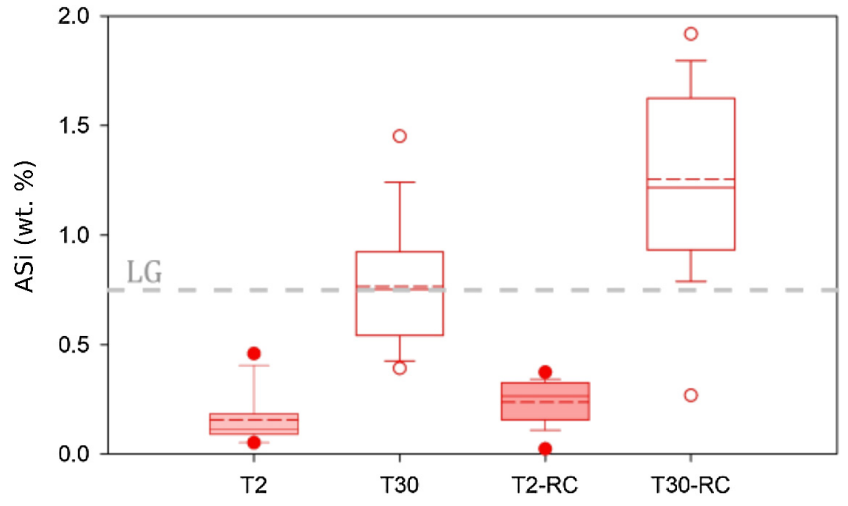

Figure 3 ASi concentrations, grouped as T2, T30 (initial milling and dissolution), and T2-RC, T30-RC (secondary crushing and dissolution), with median (solid) and mean (dashed) shown. Grey dashed line represents discharge weighted mean ASi concentration from proglacial river of Leverett Glacier (LG) in 2015 (Hatton et al., 2019a).

comminution and associated breakdown of crystalline structures (Yund et al., 1990).

A confounding factor is that HR-TEM photomicrographs indicate the presence of amorphous $\mathrm{SiO}_{2}$ nanoparticle aggregates in all samples (Fig. 4). There was also no statistical difference in overall crystallinity between starting material and milled material when completing pair distribution function (PDF) analysis of the $X$-ray scattering, though observable peak differences were present (Fig. S-4). These small concentrations of chemically sourced ASi observable under HR-TEM, likely result from environmental preweathering. Despite this, the low ASi concentrations of unmilled control experiments (avg. $0.11 \%$ d.w.; Table S-6) combined with the elevated ASi concentrations for all T30 experiments (avg. $1.03 \%$ d.w.), provide strong evidence for the importance of intense physical erosion in amorphisation and the mobilisation of pre-existing reactive $\mathrm{Si}$, mimicking the subglacial environment.

The $\delta^{30} \mathrm{Si}_{\mathrm{ASi}}$ composition (Fig. 2) was not significantly different over the incubation timescale (ANOVA, $p$ value 0.06), between T2 and T30 (ANOVA, p value 0.83), and after recrushing (ANOVA, $p$ value 0.87), with an overall average $\delta^{30} \mathrm{Si}_{\mathrm{ASi}}$ of $-0.22 \pm 0.15 \%$ ( $2 \mathrm{~s}$.d.). It is likely that this relatively consistent $\delta^{30} \mathrm{Si}_{\mathrm{ASi}}$ composition is linked to the large ASi reservoir compared to DSi. Our experimental values are similar in composition to field measurements over a summer melt season at LG (-0.32 to $-0.11 \%$; Hatton et al., 2019a), demonstrating the likely similarities between the subglacial processes forming $\mathrm{ASi}$ in the field and in our experiments.

\section{Implications for Subglacial Silicon Cycling}

Our findings highlight the importance of mechanochemical processes beneath glaciers for silicon cycling despite near freezing water temperatures. Our study improves understanding of the mechanistic drivers of subglacial Si cycling, which will help inform wider biogeochemical models. Our experiments highlight the potential of glacial physical weathering in creating high concentrations of labile ASi and a distinct isotopic signature for DSi. Physical erosion appears essential in creating fresh reactive mineral surfaces that lead to the dissolution of isotopically light DSi in subglacial environments. It is therefore likely that actively eroding glaciers with high suspended sediment concentrations and an active subglacial hydrological system will export 

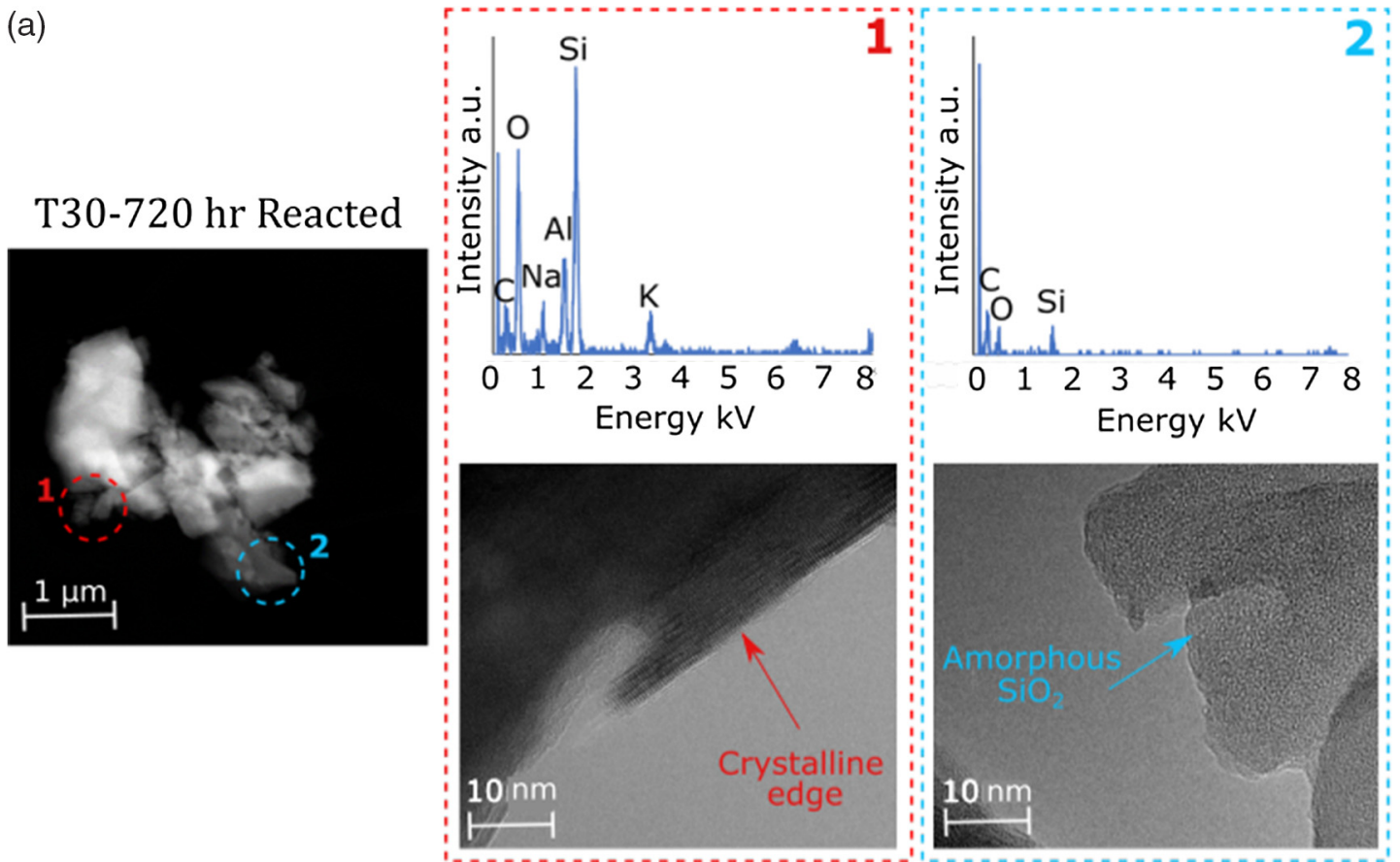

(b)
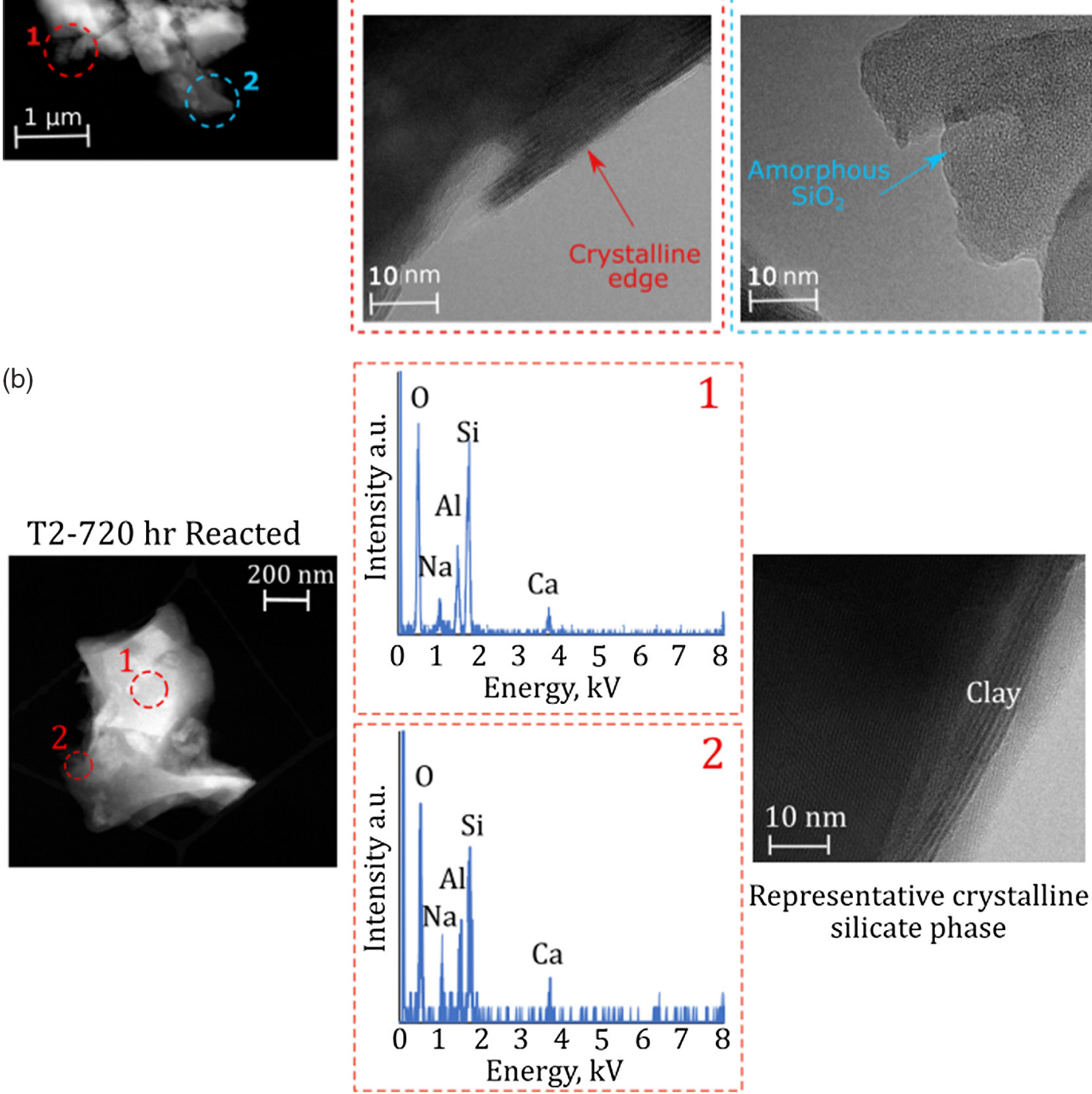

Figure 4 High-resolution transmission electron microscopy (HR-TEM) photomicrographs and energy-dispersive X-ray spectra (EDS) of particles from T30-720 hr and T2-720 hr. (a1) Representative crystalline edge and EDS spectra, likely plagioclase. (a2) Representative amorphous area, containing $\mathrm{Si}$ and $\mathrm{O}$, indicative of ASi. (b) Crystalline silicate phases representative of T2-720 hr.

meltwaters with isotopically light DSi compared to non-glacial rivers. The variation in $\delta^{30} \mathrm{Si}_{\mathrm{DSi}}$ composition and ASi concentrations between glacierised catchments could be explained by differences in erosional processes, such as heterogeneity within and between glacial ice flow rates, subglacial hydrological conditions, starting bedrock composition, and resulting mobilised sediment surface areas. Further work considering mechanistic processes using pristine starting minerals could be beneficial. Such work, combined with our findings would be key to informing a developed conceptual model of glacial biogeochemical weathering processes to consider the sensitivity of glacier and ice sheet melt to climatic warming, and the potential role of these systems in global elemental cycling.

\section{Author Contributions}

JEH and KRH conceived the study. JEH, RB, VR, LGB, HCN and TW completed laboratory analysis. All authors were involved in writing the manuscript, data interpretation and discussion. 


\section{Acknowledgements}

The authors thank the fieldwork team at Leverett Glacier for all the hard work during the 2015 field season. The authors are also grateful for laboratory support within the Bristol Isotope Group (BIG), with particular thanks Dr. Christopher D. Coath and Dr. Lucie Cassarino. Thanks also goes to laboratory support from the LowTex and Microbeam laboratories at the University of Bristol, especially Dr. Fotis Sgouridis, Miss Ioanna Petropoulou and Dr. Stuart Kearns.

JEH and KRH were funded by ERC Starting Grant ICYLAB (grant agreement 678371). NERC standard grant DELVE (NE/I008845/1), Leverhulme Research Grant RPG-2016-439. JRH was further supported by an EC Horizon 2020 Marie Skłodowska-Curie Actions fellowship (grant agreement 793962) and JLW was supported by a Royal Society Wolfson Merit Award. The GFZ team acknowledges financial support from the Helmholtz Recruiting Initiative (Award No. I-044-16-0).

Editor: Gavin Foster

\section{Additional Information}

Supplementary Information accompanies this letter at https:// www.geochemicalperspectivesletters.org/article2126.

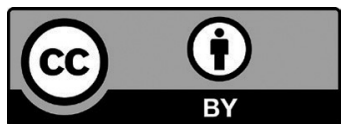

(C) 2021 The Authors. This work is distributed under the Creative Commons Attribution 4.0 License, which permits unrestricted use, distribution, and reproduction in any medium, provided the original author and source are credited. Additional information is available at http://www.geochemicalperspectivesletters.org/ copyright-and-permissions.

Cite this letter as: Hatton, J.E., Hendry, K.R., Hawkings, J.R., Wadham, J.L., Benning, L.G., Blukis, R., Roddatis, V., Ng, H. C., Wang, T. (2021) Physical weathering by glaciers enhances silicon mobilisation and isotopic fractionation. Geochem. Persp. Let. $19,7-12$.

\section{References}

Basile-Doelsch, I., Meunier, J.D., Parron, C. (2005) Another continental pool in the terrestrial silicon cycle. Nature 433, 399-402.

Blackburn, T., Siman-Tov, S., Coble, M.A., Stock, G.M., Brodsky, E.E., Hallet, B. (2019) Composition and formation age of amorphous silica coating glacially polished surfaces. Geology 47, 347-350.

Casey, W.H., Westrich, H.R., Banfield, J.F., Ferruzzi, G., Arnold, G.W. (1993) Leaching and reconstructing at the surface of dissolving chain-silicate minerals. Nature 366, 253-256.

Demarest, M.S., BRZEZINSki, M.A., Beucher, C.P. (2009) Fractionation of silicon isotopes during biogenic silica dissolution. Geochimica et Cosmochimica Acta $73,5572-5583$

Frings, P.J., Clymans, W., Fontorbe, G., De La Rocha, C., Conley, D.J. (2016) The continental Si cycle and its impact on the ocean Si isotope budget. Chemical Geology 425, 12-36.

Hatton, J.E., Hendry, K.R., Hawkings, J.R, Wadham, J.L, Kohler, T J Stibal, M BeAton, A.D., Bagshaw, E.A., Telling, J. (2019a) Investigation of subglacial weathering under the Greenland Ice Sheet using silicon isotopes. Geochimica et Cosmochimica Acta 247, 191-206.

Hatton, J.E., Hendry, K.R., Hawkings, J.R., Wadham, J.L., Opfergelt, S., Kohler, T. J., YDE, J.C., STIBAL, M., ZARSKY, J.D. (2019b) Silicon Isotopes in Arctic and sub-Arctic Glacial Meltwaters: The Role of Subglacial Weathering in the Silicon Cycle. Proceedings of the Royal Society A. 475, 20190098.

Hawkings, J.R., Wadham, J.L., Tranter, M., Lawson, E., Sole, A., Cowton, T., Tedstone, A.J., Bartholomew, I., Nienow, P., Chandler, D., Telling, J. (2015) The effect of warming climate on nutrient and solute export from the Greenland Ice Sheet. Geochemical Perspectives Letters 1, 94-104.
HaWkings, J.R., WadHAM, J.L., Benning, L.G., HendRY, K.R., TRANTER, M., Tedstone, A., Nienow, P., Raiswell, R. (2017) Ice sheets as a missing source of silica to the polar oceans. Nature Communications 8, 14198.

Hawkings, J.R., Hatton, J.E., Hendry, K.R., de Souza, G.F., Wadham, J.L., Ivanovic, R, Kohler, T.J., Stibal, M., Beaton, A, Lamarche-Gagnon, G, Tedstone, A., Hain, M.P., Bagshaw, E., Pike, J., Tranter, M. (2018) The silicon cycle impacted by past ice sheets. Nature Communications 9, 3210.

Hellmann, R., Wirth, R., Daval, D., Barnes, J.-P., Penisson, J.-M., Tisserand, D., EPICIER, T., Florin, B., Hervig, R.L. (2012) Unifying natural and laboratory chemical weathering with interfacial dissolution-reprecipitation: A study based on the nanometer-scale chemistry of fluid-silicate interfaces. Chemical Geology 294-295, 203-216.

Hendry, K.R., Huvenne, V.A.I., Robinson, L.F., AnnetT, A., Badger, M., Jacobel, A.W., NG, H.C., Opher, J., Pickering, R.A., Taylor, M.L., Bates, S.L., CoOper, A., Cushman, G.G., Goodwin, C., Hoy, S., Rowland, G., Samperiz, A., Williams, J.A., Achterberg, E.P., Arrowsmith, C., Alexander Brearley, J., Henley, S.F., Krause, J.W., Leng, M.J., Li, T., McManus, J.F., Meredith, M. P., Perkins, R., Woodward, E.M.S. (2019) The biogeochemical impact of glacial meltwater from Southwest Greenland. Progress in Oceanography 176, 102126.

Michaud, A.B., Skidmore, M.L., Mitchell, A.C., Vick-Majors, T.J., Barbante, C., Turetta, C., vanGelder, W., Priscu, J.C. (2016) Solute sources and geochemical processes in Subglacial Lake Whillans, West Antarctica. Geology 44, 347-350

Opfergelt, S. Burton, K.W, Pogge von Strandmann, P.A.E., Gislason, S.R. HallidaY, A.N. (2013) Riverine silicon isotope variations in glaciated basaltic terrains: Implications for the Si delivery to the ocean over glacial-interglacial intervals. Earth and Planetary Science Letters 369-370, 211-219.

Sharp, M., Tranter, M. (2017) Glacier Biogeochemistry. Geochemical Perspectives 6, 173-174.

Telling, J., Boyd, E.S., Bone, N., Jones, E.L., Tranter, M., MacFarlane, J.W., Martin, P.G., Wadham, J.L., Lamarche-Gagnon, G., Skidmore, M.L., Hamilton, T.L., Hill, E., Jackson, M., Hodgson, D.A. (2015) Rock comminution as a source of hydrogen for subglacial ecosystems. Nature Geoscience $8,851-855$

Wadham, J.L., Tranter, M., Skidmore, M., Hodson, A.J., Priscu, J., Lyons, W.B., SHARP, M., WrnN, P., JACKSON, M. (2010) Biogeochemical weathering under ice: Size matters. Global Biogeochemical Cycles 24, GB3025.

Yund, R.A., Blanpied, M.L., Tullis, T.E., WeEks, J.D. (1990) Amorphous material in high strain experimental fault gouges. Journal of Geophysical Research 95, 15589-15602.

Ziegler, K., Chadwick, O.A., BrzeZinski, M.A., Kelly, E.F. (2005) Natural variations of $\delta^{30} \mathrm{Si}$ ratios during progressive basalt weathering, Hawaiian Islands. Geochimica et Cosmochimica Acta 69, 4597-4610. 